\title{
A MODERN APPROACH FOR FERTIGATION UNDER GATED PIPES TECHNIQUE AND ITS IMPACT ON MAIZE PRODUCTIVITY AT NORTH NILE DELTA \\ Taha, A. A.*; M. M. Ragab ${ }^{\star *}$; A. A. Mosa* and M. M. Shabana** \\ * Soils Dept., Fac. Agric. Mansoura University \\ ${ }^{\star *}$ Soils, Water and Environment Res. Inst., Agric. Res. Center Egypt.
}

\begin{abstract}
For improving nitrogen utilization efficiency by maize crop under gated pipes irrigation technique, a field experiment was conducted at El-Hamoul district, Kafr Elshiekh governorate during the summer season of 2011. The experiment included traditional furrow irrigation, gated pipes and alternative furrows irrigation by gated pipes technique, Two forms of mineral nitrogen fertilizers Urea $\left(\mathrm{CO}\left(\mathrm{NH}_{2}\right)_{2}\right)$ and

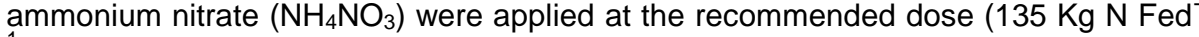
$\left.{ }^{1}\right)$ either as soil dressing or through irrigation as compared with the control treatment (without nitrogen application),

The main obtained results could be summarized as follows:

- Using gated pipes technique for irrigating maize crop resulted in less amount of water applied compared to traditional furrow irrigation method. On the other hand, gated pipes technique saved irrigation water by 19.74 and $30.77 \%$ for gated pipe and alternative gated pipes techniques, respectively as compared with traditional furrow irrigation. This improved irrigation techniques led to decrease actual water consumptive use, improved water application efficiency and increased the contribution of ground water table in the crop water need.

- There was no effect on maize yield due to different irrigation techniques. However, gated pipes and alternative gated pipes recorded the highest values of grain yield (3.3 and $2.6 \%$ ) and stalk yield (47.6 and 15.1\%) over the traditional furrow irrigation, respectively. Whereas, maize grain yield increased by about $62.1,59.7$, 58.8 and 45.8 over control treatment due to application of ammonium nitrate applied by dressing method, urea applied with irrigation water, urea applied by dressing method and ammonium nitrate applied with irrigation water, respectively. Maize grain yield took the same trend of stalk yield. It can be observed that gated pipes technique for all furrows under ammonium nitrate applied by dressing method achieved the highest grain and stalk yields followed by treatment alternate furrows which irrigated by gated pipes under urea applied with irrigation water.

- The highest mean values of crop and field water use efficiencies were achieved under gated pipes alternative furrow techniques and Urea applied with irrigation water.

- Nitrogen use efficiency and $\mathrm{N}$ recovery \% were increased with gated pipes irrigation techniques under ammonium nitrate applied by dressing method and urea applied with irrigation water

- Net income from water unit and economical efficiency increased with gated pipes techniques (for all furrow and alternative furrow) comparing with traditional furrow irrigation treatment.

Keywords: Furrow irrigation, Gated pipes irrigation technique, Nitrogen fertilization,
\end{abstract} Fertigation, maize crop. 


\section{INTRODUCTION}

Increasing water productivity and nitrogen utilization efficiency are the main goal for increasing the water and fertilizer use efficiency. This can be achieved by managing the controlled modern surface irrigation systems and adjusting them to soil hydraulic properties and to the water and nutritional requirements of the specific crop growth.

Maize is one of the most strategically crop in Egypt to overcome the increasing requirement of maize grain for bread industry $(20 \%$ mixed with wheat flour, so reduce the imported quantity of wheat),animal and poultry feeding as well as many industrial purposes.

Great efforts have been made by Egyptian scientists to improve maize production by increasing the efficiency of adding fertilizer due to minimizing loss of nitrogen through leaching. This can be achieved by applying nitrogen fertilizer with irrigation gated pipes technique (fertigation).

Increasing the agricultural production per unit volume of water is the main goal through increasing the water use efficiency. This goal can be achieved by advanced surface irrigation through applying gated pipes for irrigating field crops. Gated pipe could save irrigation water by $16.94 \%$ for maize compared to traditional surface irrigation (Abo Soliman et al., 2002).

On the other hand, the traditional surface irrigation system could be improved using gated pipes with the furrows or basin irrigation systems without major changes in the design or in the operating procedure of the current existed irrigation system. Gated pipes have low cost, relative high application and distribution efficiencies and it is easily to be used by the economic value experienced workers (Abou El-Soud, 2009).

Using gated pipes technique in irrigating alternative furrows under cultivation of maize and sugar beet crops combined with application of nitrogen recommended dose led to improve water and nitrogen use efficiencies, and save more irrigation water without significant reduction in maize and sugar beet yield specially, under limited of fresh water resources and high price of nitrogen fertilizers(Shabana, 2010).

It is well known that nitrogen is the most important element for plant growth and development, and it is an integral component of many compounds essential for plant growth processes including chlorophyll and many enzymes (Mkhabela et al.., 2001).

Mkhabela et al., (2001) examined in Swaziland the response of maize to different levels of nitrogen application, i.e. 0, 50, 100 and $150 \mathrm{Kg} \mathrm{N}$ ha-1. They found that grain yield and total dry matter were increased with increasing nitrogen application up to $100 \mathrm{Kg} \mathrm{N}$ ha-1.

The main objectives of this work are to find out the amount of water saving, maximum maize crop yield, water utilization and nitrogen use efficiency under different furrow irrigation systems. 


\section{MATERIALS AND METHODS}

A field experiment was conducted during the summer season of 2011 at El Hamoul District, Kafr El Shiekh Governorate (4 m altitude, $31^{\circ} 25$ $31^{-}$latitude and $31^{\circ} 0423^{-}$longitude) to study the nitrogen utilization efficiency under gated pipes irrigation technique with maize crop. To achieve this goal, the experimental field $\left(2940 \mathrm{~m}^{2}\right)$ was divided into three plots to be occupied by the studied irrigation techniques $\left(60 * 10 \mathrm{~m}^{2}\right.$ for each furrow irrigation treatments). Each experimental plot consisted of 24 rows. The gated pipes are located at the head of the field canal across the furrows and connected directly with the water pump. During maize crop, the area adjacent to maize was cultivated by rice.

The experimental design was Split Block design, the main plots were devoted to irrigation treatments which included three techniques (I), as follows:

- The traditional furrow irrigation technique $\left(\mathrm{I}_{1}\right)$

- Gated pipes irrigation technique $\left(\mathrm{I}_{2}\right)$

- alternative Gated pipe irrigation technique $\left(\mathrm{I}_{3}\right)$ (irrigating furrow and left the other furrow)., and

The sub plots were assigned to nitrogen application treatments, which were:

- $\mathrm{N}_{1}$ - control treatment $\left(0 \mathrm{Kg} \mathrm{N} \mathrm{Fed}^{-1}\right)$

- $\mathrm{N}_{2}$ - nitrogen was applied by dressing method in form of urea $\left.\mathrm{CO}\left(\mathrm{NH}_{2}\right)_{2}\right)$ at the recommended dose $\left(135 \mathrm{Kg} \mathrm{N} \mathrm{Fed}^{-1}\right)$.

- $\mathrm{N}_{3^{-}}$nitrogen was applied by dressing method in form $\left(\mathrm{NH}_{4} \mathrm{NO}_{3}\right)$ ammonium nitrate (Recommended dose).

- $\mathrm{N}_{4}$ - Urea applied with irrigation water. (Recommended dose).

- $\mathrm{N}_{5}$ - Ammonium nitrate applied with irrigation water. (Recommended dose). The recommended dose is $135 \mathrm{Kg} \mathrm{N} \mathrm{Fed}^{-1}$.

Urea and ammonium nitrate fertilizer added with irrigation water through modified fertilizer unit connected to pump machine under furrow irrigation techniques. The fertilizer unit made from PVC tank (50 liter) connected to suction pipes through steel valve. The fertilizers dissolved in water then transported through delivery pipes. The cost of this fertigation process heads which included the PVC tank and valve is low and not expensive.

Maize grains, cultivar triple cross (Sakha 324) were sown on June $15^{\text {th }}$, 2011. Nitrogenous fertilizers in the form of urea and ammonium nitrate were divided into three equal doses, the first dose was applied before the second irrigation, the second dose was applied before (the third irrigation) and the third dose was applied before the fourth irrigation. Potassium fertilizer (recommended dose) was applied as potassium sulphate $\left(48 \% \mathrm{~K}_{2} \mathrm{O}\right)$, and Phoshorus (recommended dose) in the from of Ca-superphosphate $\left(15.5 \% \mathrm{P}_{2} \mathrm{O}_{5}\right)$ were added with soil preparation.

\section{Soil analysis}

- Soil samples were collected from different layers and subjected to the following hydrophysico- chemical analysis according to Richards (1954) and Jackson (1967). 
- Moisture parameters; Field capacity (F.C.) and permanent wilting point (P.W.P) were determined by pressure membrane method according to Klute (1986).

- Some chemical and physical properties of the experimental soil are shown in Tables (1-2).

Table (1): Some chemical properties of the experimental soil before the growing season

\begin{tabular}{|c|c|c|c|c|c|c|c|c|c|}
\hline \multirow[b]{2}{*}{$\begin{array}{l}\text { Soil depth } \\
\text { (cm) }\end{array}$} & \multicolumn{3}{|c|}{$\begin{array}{l}\text { Particle size } \\
\text { distribution }\end{array}$} & \multirow[b]{2}{*}{ Texture } & \multirow{2}{*}{$\begin{array}{c}\text { Basic } \\
\text { infiltration } \\
\text { rate } \\
(\mathrm{cm} / \mathrm{hr})\end{array}$} & \multirow{2}{*}{$\begin{array}{c}\text { Bulk } \\
\text { density } \\
\left(\mathrm{g} / \mathrm{cm}^{3}\right)\end{array}$} & \multicolumn{3}{|c|}{$\begin{array}{l}\text { Soil moisture } \\
\text { characteristics }\end{array}$} \\
\hline & $\begin{array}{c}\text { Sand } \\
\%\end{array}$ & $\begin{array}{l}\text { Silt } \\
\%\end{array}$ & $\underset{\%}{\text { Clay }}$ & & & & \begin{tabular}{|c|} 
Field \\
capacity \\
$\%$
\end{tabular} & $\begin{array}{c}\text { Wilting } \\
\text { point } \\
\%\end{array}$ & $\begin{array}{c}\text { Available } \\
\text { water } \\
\%\end{array}$ \\
\hline $0-15$ & 16.89 & 23.97 & 59.14 & clayey & \multirow{4}{*}{1.4} & 1.16 & \begin{tabular}{|l|}
41.1 \\
\end{tabular} & 22.3 & 18.8 \\
\hline & .55 & & .88 & clayey & & 1.2 & 40.1 & 21.8 & 18.3 \\
\hline-45 & 16.22 & 24.52 & 59.26 & clay & & & 38.6 & 20.8 & 17.8 \\
\hline $45-60$ & 17.60 & 26.26 & 56.14 & clayey & & 1.37 & 38.2 & 20.7 & 17.5 \\
\hline
\end{tabular}

${ }^{*} \mathrm{pH}$ was determined in soil water suspension (1:2.5).

${ }^{\star *} \mathrm{EC}$ was determined in saturated soil paste extract.

Table (2). Some physical properties of the experimental soil before the growing season.

\begin{tabular}{|c|c|c|c|c|c|c|c|c|c|c|c|c|c|c|}
\hline \multirow{2}{*}{$\begin{array}{l}\text { Soil } \\
\text { depth } \\
\text { (cm) }\end{array}$} & \multirow{2}{*}{$\begin{array}{c}\text { OM } \\
\%\end{array}$} & \multirow[t]{2}{*}{$\mathbf{p H}^{\star}$} & \multirow{2}{*}{$\begin{array}{l}E C^{\star \star} \\
(\mathrm{dS} / \mathrm{m})\end{array}$} & \multicolumn{4}{|c|}{$\begin{array}{c}\text { Soluble cations } \\
\left(\mathrm{meq} \mathrm{L}^{-1}\right)\end{array}$} & \multicolumn{3}{|c|}{$\begin{array}{l}\text { Soluble anions } \\
\left.\text { (meq } L^{-1}\right)\end{array}$} & \multirow[t]{2}{*}{ SAR } & \multicolumn{3}{|c|}{$\begin{array}{c}\text { Available } \\
\text { nutrients (ppm) }\end{array}$} \\
\hline & & & & $\mathrm{Na}^{+}$ & $\mathrm{K}^{+}$ & $\mathrm{Ca}^{++}$ & $\mathbf{M g}^{++}$ & $\mathrm{CO}^{\circ}$ & $\mathrm{HCO}^{-3} \mathrm{Cl}^{-}$ & SO4"- & & $\mathbf{N}$ & $\mathbf{P}$ & $\mathrm{K}$ \\
\hline $0-15$ & 1.21 & 8.25 & 243 & 16.5 & 0.2 & 3.9 & 5.3 & 0 & \begin{tabular}{|l|l|}
5.2 & 11.6 \\
\end{tabular} & 9 & 7.69 & 59.3 & 9.4 & 331 \\
\hline $15-30$ & 20 & 8.22 & & 19.4 & 0.3 & 4.6 & 6.3 & 0 & \begin{tabular}{l|l|}
7.1 & 13.6 \\
\end{tabular} & 9.7 & 8.33 & 63.8 & 9.9 & 333 \\
\hline $30-45$ & 0.91 & 8.26 & & 23.8 & 0.4 & 5.6 & 7.7 & 0 & \begin{tabular}{|l|l|}
7.8 & 16.7 \\
\end{tabular} & 12.1 & 9.23 & 42.6 & 9.6 & 323 \\
\hline $45-60$ & 56 & 8.29 & 6.17 & 42.0 & 0.6 & 9.9 & 13.6 & 0 & \begin{tabular}{|l|l|}
7.5 & 29.4 \\
\end{tabular} & 29.1 & 12.25 & 31.9 & 9.5 & 317 \\
\hline
\end{tabular}

- Amount of water applied:-

Traditional surface irrigation: the applied irrigation water was measured by using cut -throat flume $(20 \times 90 \mathrm{~cm})$ according to Early (1975).

Improved surface irrigation (gated pipes): the discharge through an orifice was determined as described by (Brater and King 1976). Applied water (AW): was calculated as described by Giriappa (1983) as follows: $A W=I W+E R+S$, where $I W=$ irrigation water applied, $E R=$ effective rain and $S=$ amount of soil moisture contribution to consumptive use from the shallow ground water table.

- Contribution of ground water table as a percentage of the consumptive use was calculated as follows:

GWC\% $=(E T c-S M D) / E T c \times 100$, where $E T C=$ Crop evapotarnspiration = EToxKc and SMD= soil moisture depletion. (Cited from Khalifa, 2013)

- Water consumptive use (CU): was calculated using the equation of Israelson and Hansen (1962).

- Irrigation application efficiency (Ea): Values of irrigation application efficiency (Ea) in percent for each treatment were obtained according to Downy (1970) as follows: 


$$
\mathrm{Ea}=\frac{\mathrm{Ws} \times 100 \quad \text { where: }}{\mathrm{Wd}}
$$

$\mathrm{Ea}=$ Water application efficiency $(\%)$

$W s=$ Water stored in the effective root zone

$\mathrm{Wd}=$ Water applied to the field plot.

- Maize yield: data of the grain yield was adjusted based on the moisture percent of $15.5 \%$

- Crop water use efficiency (CWUE).

It was calculated by the following equation according to Abd El -Rasool et al., (1971).

$$
\text { C.W.U .E. }=\frac{\text { Yield }\left(\mathrm{Kg} \mathrm{fed}^{-1}\right)}{\text { Water consumptive use }\left(\mathrm{m}^{3} \mathrm{fed}^{-1}\right)}
$$

- Field water use efficiency (FWUE).

It was calculated in $\mathrm{Kg} \mathrm{m}^{-3}$ for different irrigation systems to clarify how much $\mathrm{Kg}$ yield is produced from one cubic meter applied (Michael,1978)

- Nitrogen in plant: was determined in grain and stalk digestion by microKjeldahl method as explained by Hesse (1971). The uptake of nutrients by plant organs (grain and stalk) was calculated by multiplying element concentration by dry weight of plant for maize.

- Nitrogen use efficiency was calculated as grain yield $(\mathrm{Kg})$ produced due to adding unit of nitrogenous fertilizer.

- $\quad$ Nitrogen recovery \%

Apparent nitrogen recovery of fertilizer (\%) was calculated for each treatment according to the following equation (Crasswell and Godwin , 1984)

Recovery of $\mathbf{N}$ fertilizer \% =

\section{Statistical analysis}

$$
\mathrm{N} \text {-applied from fertilizer }
$$

Data were statistically analyzed using analysis of variance (ANOVA). Treatments means and significance of differences were calculated and presented using (LSD) according to Duncan (1955). All statistical analyses were performed using analysis of variance technique by mean of $\mathrm{CoHort}$ Computer software

\section{RESULTS AND DISCUSSION}

\section{Some water relations:-}

\section{Amount of irrigation water applied.}

Data in Table (3) show that using gated pipes techniques resulted in less amount of water applied compared to traditional furrow method. The lowest amounts of water applied were achieved by $\mathrm{I}_{3}$ (alternative gated pipes technique), followed by $I_{2}$ (gated pipes technique), where the highest one was obtained from traditional method $l_{1}$. It is worthy to mention that, gated pipes 
technique saved irrigation water by 19.74 and $30.77 \%$ for $I_{2}$ and $I_{3}$, respectively. These results are in a good agreement with those obtained by Abo Soliman, et al. (2002) and Abou El-Soud (2009).

Contribution of ground water to ETc $(\mathrm{cm})$ :-

Values of contribution of ground water to maize crop are presented in Table (3). Data reveal that by increasing the water applied, less values of contribution of ground water table $(\mathrm{cm})$ was obtained. So, less contribution (S) was obtained under using traditional surface furrow irrigation $\left(I_{1}\right)$ which was found $13.97 \mathrm{~cm}$ (as an average). These results are in harmony to those recorded by khalifa (2013)

On the other hand, the highest ground water contribution was obtained under $I_{3}$ techniques $(14.39 \mathrm{~cm})$. So, contribution of $\mathrm{GW}$ was increased directly by increasing the water applied from the area adjacent to maize is cultivated by rice, this resulted in water movement causing upward flow and contribution the water table in irrigation. The less contribution of water table might be attributed to the less water consumed by plants at both early and maturity stages. Results of ground water contribution could be differed according to the growth, irrigation treatments and water table depth (Kahlown et al., 2005).

Water stored:-

Water stored in the effective root zone (Table 3 ) is one of the most important criteria which related to the field irrigation efficiency with different furrow irrigation techniques. Meanwhile, the highest amount of water stored under maize crop is $2369.64 \mathrm{~m}^{3}$ fed $^{-1}$ under traditional surface furrow irrigation, while the lowest of amount water stored was obtained under alternate furrow irrigated by gated pipes $\left(\mathrm{I}_{3}\right)$ technique $\left(1805.58 \mathrm{~m}^{3} \mathrm{fed}^{-1}\right)$.

Actual water consumptive use:-

Data in Table (3) indicate that the seasonal water consumptive use values by maize crop were affected by furrow irrigation methods. The highest value $\left(2359.79 \mathrm{~m}^{3} \mathrm{fed}^{-1}\right)$ was obtained from traditional furrow irrigation technique $\left(I_{1}\right)$, while, the lowest one was obtained under $\left(I_{3}\right)$ alternative gated pipes technique $\left(1768.47 \mathrm{~m}^{3}\right.$ fed $^{-1}$ ) followed by gated pipes technique $\left(I_{2}\right)$. These results are in somewhat similar to those recorded by Abo Soliman et al., (2002) and Abou El-Soud (2009).

Water application efficiency:-

Data in Table (3) reveal that the highest value of water application efficiency $(74.66 \%)$ was achieved under gated pipes $\left(I_{2}\right)$, while the lowest one $(66.15 \%)$ was detected under $\left(I_{1}\right)$ treatment. It was expected that application efficiency was improved by $8.5 \%$ and $6.7 \%$ due to irrigation with gated pipe $\left(I_{2}\right)$ and alternative gated pipe $\left(I_{3}\right)$, respectively compared to traditional irrigation $\left(\mathrm{I}_{1}\right)$. This may be due to the uniform water distribution from the outlet of gated pipe compared to traditional surface irrigation which tend to reduce the percolation losses. These results agreed with numerous investigators like Abo Soliman et al., (2002) and Abou El-Soud (2009). 
Table (3): Water consumptive use, water stored, water applied (IW and S), water saving \% and irrigation water applied efficiency $\%$ as affected by different treatments during maize growing season.

\begin{tabular}{|c|c|c|c|c|c|c|c|}
\hline \multirow[t]{2}{*}{ 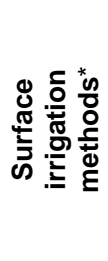 } & \multirow[t]{2}{*}{ 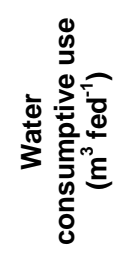 } & \multirow[t]{2}{*}{ 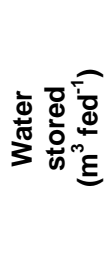 } & 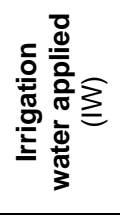 & 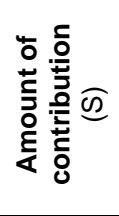 & $\begin{array}{l}\frac{\bar{d}}{\pi} \\
\frac{0}{3} \\
\frac{d}{\frac{d}{2}} \\
\frac{0}{\frac{0}{2}}\end{array}$ & \multirow[t]{2}{*}{ 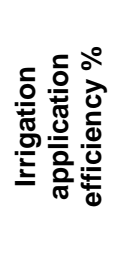 } & \multirow[t]{2}{*}{ 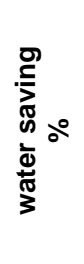 } \\
\hline & & & \multicolumn{3}{|c|}{$\left(m^{3}\right.$ fed $\left.^{-1}\right)$} & & \\
\hline$I_{1}$ & 2359.79 & 2369.64 & 3003.00 & 579.18 & 3582.18 & 66.15 & 0 \\
\hline $\mathrm{I}_{2}$ & 2048.21 & 2146.62 & 2320.92 & 553.98 & 2874.90 & 74.66 & 19.74 \\
\hline$I_{3}$ & 1768.47 & 1805.58 & 1875.30 & 604.38 & 2480.10 & 72.81 & 30.77 \\
\hline
\end{tabular}

I3: Alternate furrow irrigation by Gated pipes

Yield:

Irrigation effect:

Data in Table (4) reveal that an insignificant effect on grain and stalk yield of maize was obtained due to irrigation treatments. Modern irrigation techniques $\left(I_{2}\right.$ and $\left.I_{3}\right)$ treatments led to increase grain yield (3.3 and $\left.2.6 \%\right)$ and stalk yield by (47.6 and $15.1 \%)$ as compared to traditional surface irrigation $\left(\mathrm{I}_{1}\right)$, respectively.

\section{Nitrogen fertilization effect}

As shown in Table (4) high significant effect due to forms and method of application nitrogen fertilizer was resulted on grain and stalks yield. the highest grain yield was achieved by using $\left(\mathrm{N}_{3}\right)$ Ammonium nitrate applied by dressing method, which produced the highest mean values of maize grain yield $\left(4285.3 \mathrm{Kg} \mathrm{Fed}^{-1}\right)$ followed by $\left(\mathrm{N}_{4}\right)$ Urea applied with irrigation water(4199.8 $\left.\mathrm{Kg} \mathrm{Fed}^{-1}\right)$.

Maize grain yield increased by about $62.1 \%, 59.7 \%, 58.8 \%$ and $45.8 \%$ over control treatment $\left(0 \mathrm{Kg} \mathrm{N}\right.$ Fed - 1 ) due to application of $\mathrm{N}_{3}, \mathrm{~N}_{4}, \mathrm{~N}_{2}$ and $\mathrm{N}_{5}$, respectively. The grain yield is reflection of stalk yield, so it is logically that maize grain yield took the same trend of stalk yield.

It is well known that nitrogen is the most important element for plant growth and development, and it is an integral component of many compounds essential for plant growth processes including chlorophyll and many enzymes (Mkhabela et al.., 2001). 
Table (4): Effect of irrigation and nitrogen fertilization on grain and stalk yield $\left(\mathrm{Kg} \mathrm{fed}^{-1}\right)$ of maize crop.

\begin{tabular}{|c|c|c|c|c|}
\hline Treatments & $\begin{array}{l}\text { Grain yield } \\
\left(\mathrm{Kg} \mathrm{fed}^{-1}\right)\end{array}$ & $\begin{array}{c}\text { Relative } \\
\text { change \% }\end{array}$ & $\begin{array}{l}\text { Stalk yield } \\
\left(\mathrm{Kg} \mathrm{fed}^{-1}\right)\end{array}$ & $\begin{array}{c}\text { Relative change } \\
\%\end{array}$ \\
\hline \multicolumn{5}{|c|}{ Irrigation Treatment } \\
\hline$I_{1}$ & $3607.13 a$ & 0.0 & $13069.33 \mathrm{c}$ & 0.0 \\
\hline$I_{2}$ & $3727.03 a$ & +3.3 & $14785.33 a$ & +47.6 \\
\hline$I_{3}$ & $3701.91 a$ & +2.6 & $13613.33 b$ & +15.1 \\
\hline F-Test & ns & - & $* * *$ & - \\
\hline LSD at 0.05 & 120.10 & - & 193.89 & - \\
\hline \multicolumn{5}{|c|}{ Nitrogen fertilization } \\
\hline$N_{1}$ & $2044.87 c$ & 0.0 & $10116.66 \mathrm{e}$ & 0.0 \\
\hline $\mathrm{N}_{2}$ & $4167.52 \mathrm{a}$ & +58.8 & $14483.33 c$ & +121.1 \\
\hline $\mathrm{N}_{3}$ & $4285.32 a$ & +62.1 & $15670 a$ & +154.0 \\
\hline $\mathrm{N}_{4}$ & $4199.77 a$ & +59.7 & $15101.11 b$ & +138.2 \\
\hline $\mathrm{N}_{5}$ & $3695.96 \mathrm{~b}$ & +45.8 & $13742.22 \mathrm{~d}$ & +100.5 \\
\hline F-Test & $\star * \star$ & - & $\star * *$ & - \\
\hline LSD at 0.05 & 137.15 & - & 406.7 & - \\
\hline
\end{tabular}

\section{Interaction effect:}

The influence of interaction between irrigation treatments and nitrogen fertilization on maize yield was significant for grain and stalk yield. It can be observed from Table (5) that gated pipes technique for all furrows $\left(I_{2}\right)$ under $\mathrm{N}_{3}$ achieved the highest grain and stalk yields followed by treatment $\left(I_{3}\right)$ alternate gated furrows under $\mathrm{N}_{4}$ than traditional furrow irrigation treatment $\left(I_{1}\right)$ under $N_{3}$, this is related to the improvement of soil aeration conditions, more uniformity of water distribution along the furrow, (Morsi, 2001), enhancing root system (primary root number, root density and total root dry weight), (Kang et al.., 2000) and enhancing water and nutrients uptake (Abdel-Maksoud et al.., 2002).

Table (5): The interactions effect between irrigation system and nitrogen fertilization treatments on maize grain and stalk yields $\left(\mathrm{Kg} \mathrm{Fed}^{-1}\right)$.

\begin{tabular}{|c|c|c|c|}
\hline \multicolumn{2}{|c|}{ Treatments } & Grain & Stalk \\
\hline \multirow{5}{*}{$I_{1}$} & $\mathrm{~N}_{1}$ & $1746.1 \mathrm{f}$ & $5616.66 f$ \\
\hline & $\mathrm{N}_{2}$ & $4287.4 \mathrm{abc}$ & $14580 \mathrm{~b}$ \\
\hline & $\mathrm{N}_{3}$ & 4292.73abc & 16773.33a \\
\hline & $\mathrm{N}_{4}$ & $4026.36 c$ & $14343.33 b$ \\
\hline & $\mathrm{N}_{5}$ & $3683.06 \mathrm{~d}$ & $14033.33 \mathrm{bc}$ \\
\hline \multirow{5}{*}{$I_{2}$} & $\mathrm{~N}_{1}$ & $2207.3 \mathrm{e}$ & $12356.66 \mathrm{e}$ \\
\hline & $\mathrm{N}_{2}$ & $4078.73 c$ & $14370 \mathrm{~b}$ \\
\hline & $\mathrm{N}_{3}$ & $4496.76 a$ & 16663.33a \\
\hline & $\mathrm{N}_{4}$ & $4173.4 \mathrm{bc}$ & $16356.66 a$ \\
\hline & $\mathrm{N}_{5}$ & $3678.96 \mathrm{~d}$ & $14180 \mathrm{bc}$ \\
\hline \multirow{5}{*}{$I_{3}$} & $N_{1}$ & $2181.23 \mathrm{e}$ & $12376.66 \mathrm{e}$ \\
\hline & $\mathrm{N}_{2}$ & $4136.43 \mathrm{bc}$ & $14500 \mathrm{~b}$ \\
\hline & $\mathrm{N}_{3}$ & $4066.46 \mathrm{c}$ & $13573.33 \mathrm{~cd}$ \\
\hline & $\mathrm{N}_{4}$ & 4399.56ab & $14603.33 b$ \\
\hline & $\mathrm{N}_{5}$ & $3725.86 \mathrm{~d}$ & 13013.33d \\
\hline \multicolumn{2}{|l|}{ F Test } & ** & $\star * *$ \\
\hline \multicolumn{2}{|c|}{ LSD at 0.05} & 276.16 & 597.3 \\
\hline
\end{tabular}




\section{Water use efficiency of maize:}

Data in Fig (1) show a highly significant effect of irrigation technique on crop and field water use efficiencies (CWUE and FWUE). The highest mean value (2.3 and $1.7 \mathrm{~kg}$ grain $/ \mathrm{m}^{3}$ ) was achieved under alternative gated pipes techniques $\left(\mathrm{I}_{3}\right)$ and $\left(\mathrm{N}_{4}\right)$ Urea applied through irrigation water. Whereas, the lowest mean value was detected under most of irrigation technique and zero nitrogen.

It could be observed from the data that the use of the modern gated pipes techniques $I_{2}$ and $I_{3}$ are better than the traditional surface furrow irrigation technique. The differences in FWUE and CWUE values with different furrow irrigation techniques are attributed to the amounts of the water applied and consumed as well as the crop productivity.

By other words, using modern irrigation by gated pipes improved FWUE and CWUE values. This may be attributed to the amounts of the water applied and consumed as well as the crop productivity. These results are in harmony with those recorded by Abo Soliman ,et al. (2002), Sonbol,et al. (2009) and Abou El-Soud (2009).

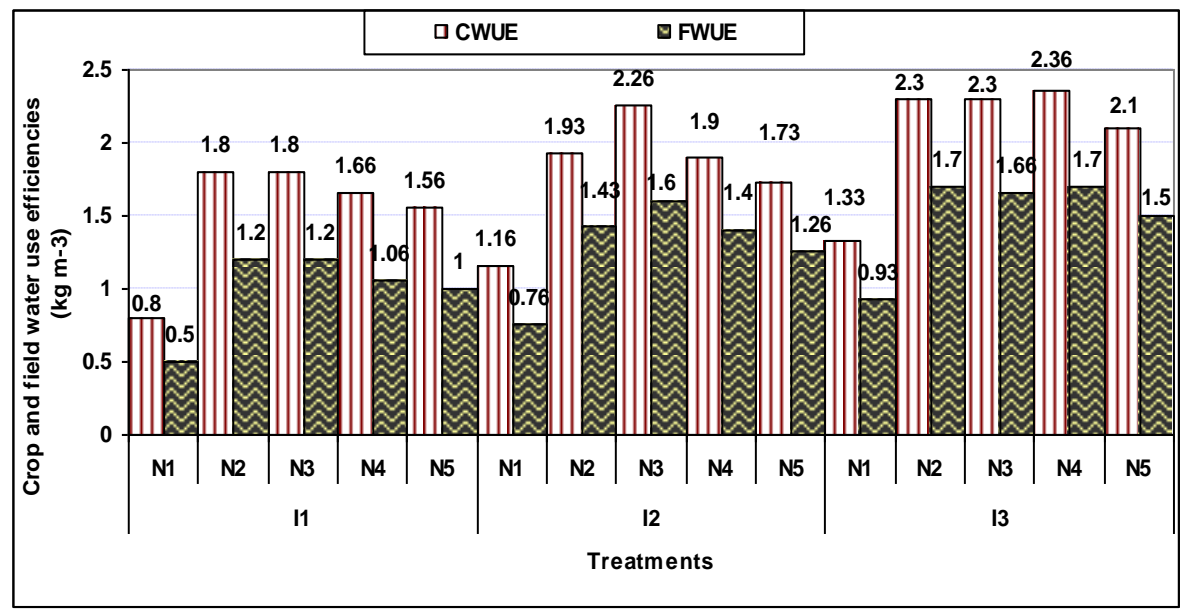

Fig (1): Crop (CWUE) and field (FWUE) water use efficiencies as affected by irrigation system and nitrogen fertilizer application methods with maize grain yield.

\section{Nitrogen concentration and uptake by maize crop: Irrigation effect:}

Data in Table (6) illustrate the impact of irrigation treatments on nitrogen concentration and its uptake by maize. It can be observed that nitrogen concentration increased under gated pipes irrigation techniques $\left(I_{2}\right.$ and $I_{3}$ ) compared to traditional irrigation treatment $\left(I_{1}\right)$.

This result may be resulted from the improving of furrow irrigation which enhanced root volume as a result of good aeration and improving soil physical properties (Kang et al.., 2000) \& (Morsi 2001), then improving root volume which increased nitrogen uptake. Similar results were also obtained by Aiad 2003 and Mosa 2006. 
The highest mean values of nitrogen concentration in maize grains and stalks are detected with $I_{2}$ followed by $I_{3}$.

Nitrogen uptake takes the same trend of nitrogen concentration, as nitrogen uptake is high significantly increased with decreasing irrigated furrows.

There is no doubt that nutrient concentration in stalk tissues reflects its concentration on grains, so it can notice from Table 6 that there is good relation between the nitrogen concentration in stalk and grains of corn.

\section{Nitrogen fertilization effect:}

Data illustrated in Table (6) show that nitrogen concentration (\%) and uptake $\left(\mathrm{Kg} \mathrm{Fed}^{-1}\right)$ of both grain and stalk organs increased with $\left(\mathrm{N}_{4}\right)$ urea applied with irrigation water and $\left(\mathrm{N}_{3}\right)$ ammonium nitrate applied by dressing method.

The highest amounts of nitrogen uptake by grains and stalks were 44.74 and $48.58 \mathrm{Kg} \mathrm{N} \mathrm{Fed}-1$ respectively were found under $\left(\mathrm{N}_{4}\right)$ and $\left(\mathrm{N}_{3}\right)$. whereas, the lowest ones were detected under control treatment (15.69 and 18.64 Kg N Fed-1) for grain and stalk, respectively.

Table (6). Effect of irrigation systems and nitrogen fertilization treatments on nitrogen concentration and uptake by maize crop.

\begin{tabular}{|c|c|c|c|c|}
\hline \multirow[t]{2}{*}{ Treatments } & \multicolumn{2}{|c|}{ Nitrogen concentration (\%) } & \multicolumn{2}{|c|}{$\begin{array}{c}\text { Nitrogen uptake } \\
\left(\mathrm{kg} \mathrm{fed}^{-1}\right)\end{array}$} \\
\hline & Grain & Stalk & Grain & Stalk \\
\hline \multicolumn{5}{|c|}{ Irrigation Treatment } \\
\hline $\mathrm{I}_{1}$ & $1.07 \mathrm{~b}$ & $1.29 \mathrm{c}$ & $33.55 \mathrm{~b}$ & $30.01 c$ \\
\hline $\mathrm{I}_{2}$ & $1.21 \mathrm{a}$ & $1.92 a$ & $38.61 \mathrm{a}$ & $48.95 a$ \\
\hline$I_{3}$ & $1.14 a b$ & $1.67 b$ & $36.31 a b$ & $38.73 b$ \\
\hline F-Test & * & $\star \star \star *$ & * & $* * *$ \\
\hline LSD at 0.05 & 0.07 & 0.059 & 3.45 & 1.58 \\
\hline \multicolumn{5}{|c|}{ Nitrogen fertilization } \\
\hline $\mathrm{N}_{1}$ & $0.90 d$ & $1.04 d$ & $15.69 d$ & $18.61 \mathrm{c}$ \\
\hline $\mathrm{N}_{2}$ & $1.13 c$ & $1.61 \mathrm{c}$ & $39.73 b$ & $39.36 b$ \\
\hline $\mathrm{N}_{3}$ & $1.21 a b$ & $1.83 a b$ & $43.57 a$ & $48.58 a$ \\
\hline $\mathrm{N}_{4}$ & $1.26 \mathrm{a}$ & $1.87 a$ & $44.74 a$ & $48.34 a$ \\
\hline $\mathrm{N}_{5}$ & $1.19 b c$ & $1.78 b$ & $37.06 \mathrm{c}$ & $41.26 b$ \\
\hline F-Test & 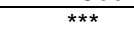 & $\star * \star$ & $\star \star \star$ & 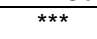 \\
\hline LSD at 0.05 & 0.06 & 0.087 & 1.38 & 2.59 \\
\hline
\end{tabular}

\section{Interactions effect:}

Data in Table (7) reveal the interaction effect between irrigation techniques and nitrogen fertilization on nitrogen concentration and uptake by grain and stalk.

Concerning nitrogen concentration and uptake, it is obvious that the interactions between irrigation and nitrogen fertilization effect were highly significant on stalk and insignificant on grains.

Regarding data of nitrogen concentration in grains and stalks, It can be observed that gated pipes irrigation techniques $\left(\mathrm{I}_{2}\right)$ under $\left(\mathrm{N}_{4}\right)$ urea applied with irrigation water was the superior irrigation treatment, and this may attributed to less nitrate leaching, and so increasing nitrogen concentration in 
soil, resulting increasing in nitrogen uptake. Similar results were obtained by Abde-Maksoud et al.., (2002) and Mosa, (2006).

Table (7). Interaction effect between irrigation and nitrogen fertilization treatments on nitrogen concentration (\%) and nitrogen uptake $\left(\mathrm{kg} \mathrm{fed}^{-1}\right)$ of grains and stalks

\begin{tabular}{|c|c|c|c|c|c|}
\hline \multirow{2}{*}{\multicolumn{2}{|c|}{ Treatments }} & \multicolumn{2}{|c|}{$\begin{array}{c}\text { Nitrogen concentration } \\
(\%)\end{array}$} & \multicolumn{2}{|c|}{$\begin{array}{l}\text { Nitrogen uptake } \\
\left(\mathrm{kg} \mathrm{fed}^{-1}\right)\end{array}$} \\
\hline & & Grain & Stalk & Grain & Stalk \\
\hline \multirow{5}{*}{$I_{1}$} & $\mathrm{~N}_{1}$ & $0.80 f$ & $0.84 f$ & $11.83 \mathrm{e}$ & $8 g$ \\
\hline & $\mathrm{N}_{2}$ & $1.07 \mathrm{de}$ & $1.34 d$ & $38.7 b$ & $33.17 \mathrm{e}$ \\
\hline & $\mathrm{N}_{3}$ & $1.18 \mathrm{bcd}$ & $1.46 \mathrm{~d}$ & $42.53 a b$ & $41.5 \mathrm{~cd}$ \\
\hline & $\mathrm{N}_{4}$ & $1.26 \mathrm{ab}$ & $1.41 d$ & 42.67ab & $34.2 \mathrm{e}$ \\
\hline & $\mathrm{N}_{5}$ & $1.03 \mathrm{e}$ & $1.39 \mathrm{~d}$ & $32 c$ & $33.2 \mathrm{e}$ \\
\hline \multirow{5}{*}{$\mathbf{I}_{2}$} & $\mathrm{~N}_{1}$ & $1.02 \mathrm{e}$ & $1.14 \mathrm{e}$ & $18.97 d$ & $23.77 f$ \\
\hline & $\mathrm{N}_{2}$ & $1.22 a b c$ & $2.02 b$ & $41.8 a b$ & $49.03 b$ \\
\hline & $\mathrm{N}_{3}$ & $1.22 a b c$ & $2.24 a$ & $46.07 a$ & $63.1 \mathrm{a}$ \\
\hline & $\mathrm{N}_{4}$ & $1.32 a$ & $2.25 a$ & $46.5 \mathrm{a}$ & $62.33 a$ \\
\hline & $\mathrm{N}_{5}$ & $1.28 \mathrm{ab}$ & $1.94 \mathrm{bc}$ & $39.73 b$ & $46.5 b c$ \\
\hline \multirow{5}{*}{$I_{3}$} & $\mathrm{~N}_{1}$ & $0.88 \mathrm{f}$ & $1.14 \mathrm{e}$ & $16.27 \mathrm{~d}$ & $24.07 f$ \\
\hline & $\mathrm{N}_{2}$ & $1.11 \mathrm{cde}$ & $1.46 \mathrm{~d}$ & $38.7 \mathrm{~b}$ & $35.87 \mathrm{e}$ \\
\hline & $\mathrm{N}_{3}$ & $1.23 a b c$ & $1.79 c$ & $42.1 \mathrm{ab}$ & $41.16 \mathrm{~d}$ \\
\hline & $\mathrm{N}_{4}$ & $1.22 a b c$ & $1.97 \mathrm{bc}$ & $45.07 a$ & $48.5 b$ \\
\hline & $\mathrm{N}_{5}$ & $1.26 a b$ & $2.01 \mathrm{~b}$ & $39.43 b$ & $44.07 \mathrm{bcd}$ \\
\hline \multicolumn{2}{|c|}{ F Test } & ns & 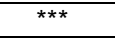 & ns & $\star \star \star *$ \\
\hline \multicolumn{2}{|c|}{ LSD at 0.05} & 0.12 & 0.182 & 4.43 & 4.86 \\
\hline
\end{tabular}

\section{Nitrogen use efficiency (NUE)}

It is defined as the amount of harvested crop which produced from the unit of nitrogen supplied during the growing season. The effects of irrigation technique on nitrogen use efficiency are shown in Fig (2). Data clearly show that the highest values of nitrogen use efficiency were obtained by gated pipes irrigation techniques $\left(\mathrm{I}_{2}\right)$ under $\left(\mathrm{N}_{3}\right)$ Ammonium nitrate $\left(\mathrm{NH}_{4} \mathrm{NO}_{3}\right)$ applied by dressing method, followed by gated pipes alternative furrow irrigation techniques $\left(I_{3}\right)$ under $\left(N_{4}\right)$ Urea applied with irrigation water and followed by traditional furrow irrigation technique $\left(I_{1}\right)$ under $\left(N_{3}\right)$ Ammonium nitrate applied by dressing method. This may be due to uniform water distribution from the outlet of gated pipes compared to traditional furrow irrigation which tends to reduce the percolation losses and less nitrate leaching, and so increasing nitrogen concentration in root zone, resulting in increasing the nitrogen uptake and increasing grain yield. Similar results were obtained by Abdel-Maksoud et al.., (2002) and Mosa, (2006).

Nitrogen -recovery:

Fig (2) shows the total nitrogen recovery by the whole maize plant (grains \& stalks) at maturity stage. The highest value of $\mathrm{N}$ recovery $\%$ was found under $\left(\mathrm{I}_{2}\right)$ with $\left(\mathrm{N}_{3}\right)$ and $\left(\mathrm{N}_{4}\right)$, followed by (I1) under $\left(\mathrm{N}_{3}\right)$ and followed by (I3) under $\left(\mathrm{N}_{4}\right)$. Similar results were obtained by Shabana (2010). 


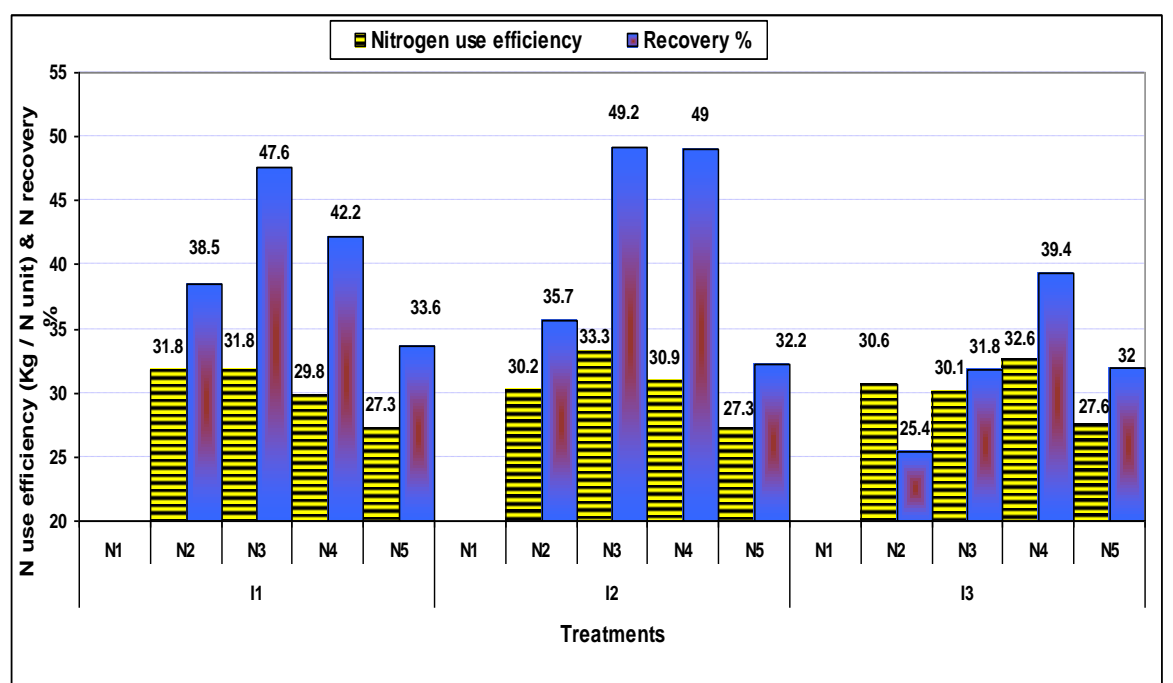

Fig (2). Effect of irrigation treatments on nitrogen use efficiency and $\mathrm{N}$ recovery for maize crop.

\section{Economical evaluation:}

Data tabulated in table ( 8 ) show that, the highest total income $(8430.3$ L.E/fed) net income (6085.3 L.E/fed) , net income from water unit (2.34 $\mathrm{L} . \mathrm{E} / \mathrm{m}^{3}$ ) and economical efficiency (2.60) were obtained with gated pipes alternative furrow irrigation techniques $\left(\mathrm{I}_{3}\right)$ under $\left(\mathrm{N}_{4}\right)$ urea applied with irrigation water, followed by $\left(\mathrm{I}_{3}\right)$ under $\left(\mathrm{N}_{3}\right)$ for total income $(8677.4 \mathrm{~L}$. E/fed) net income (5893.6 L.E/fed), net income from water unit $\left(2.07 \mathrm{L.E} / \mathrm{m}^{3}\right)$ and economical efficiency $(2.45)$ with $\left(\mathrm{N}_{4}\right)$ and $(2.12)$ with $\left(\mathrm{N}_{3}\right)$, while the lowest values of net income from water unit $\left(0.42 \mathrm{~L} . \mathrm{E} / \mathrm{m}^{3}\right)$ and economical efficiency (0.76) were recorded with traditional furrow irrigation technique $\left(I_{1}\right)$ under zero application of nitrogen.

In addition to net income from water unit and economical efficiency increased with Gated pipes $\left(\mathrm{I}_{2}\right.$ and $\mathrm{I}_{3}$ ) comparing with traditional furrow irrigation treatment $\left(I_{1}\right)$. This may be due to the uniform water distribution from the outlet gated pipes compared to traditional furrow irrigation which tends to reduce the percolation losses and less nitrate leaching, and so increasing nitrogen concentration in root zone and increasing grain yield. These results are an agreement with those recorded by khalifa (2013). 
Table (8) Net income, Net income from water unit and economical efficiency of maize crop as affected by irrigation and nitrogen fertilization treatments.

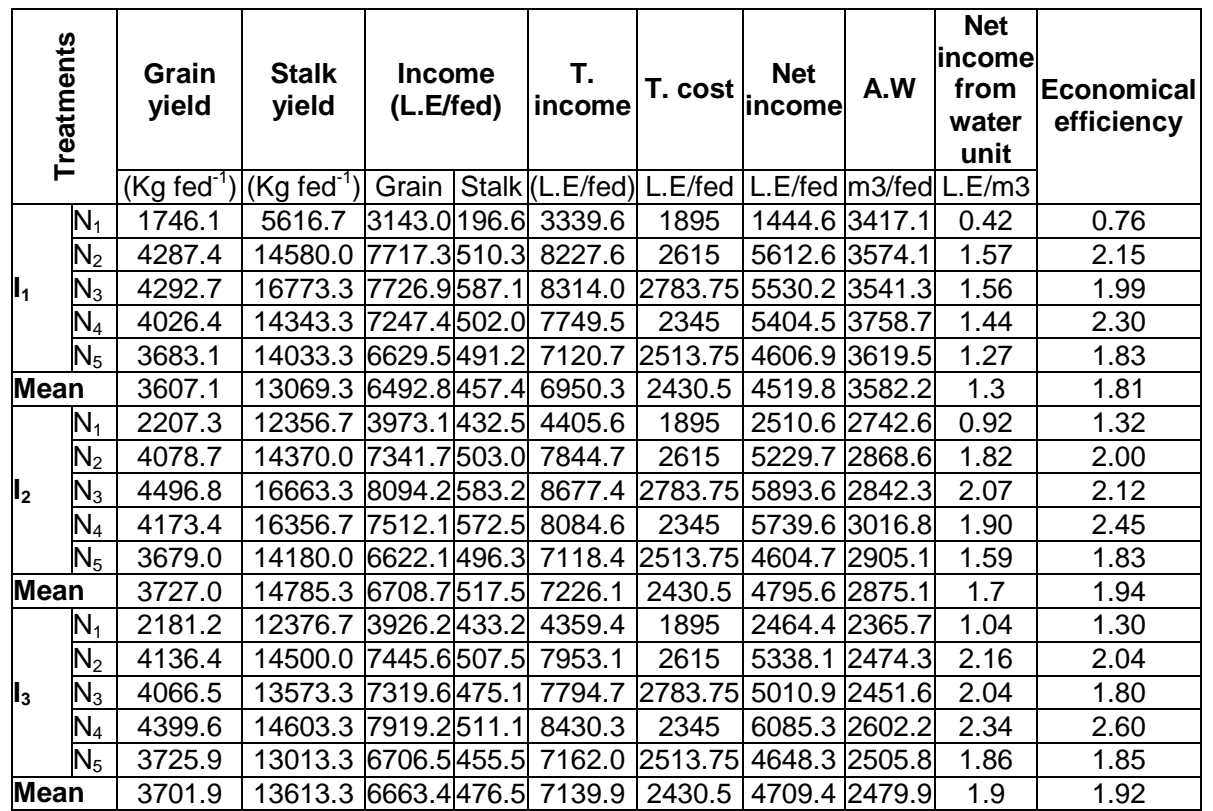

Economical efficiency= net income $/$ total cost Net

Income from water unit $(\mathrm{L} . \mathrm{E} / \mathrm{m})=$ net income /AW

\section{Conclusion}

- Using gated pipes technique for irrigating maize crop in combination with application of urea applied with irrigation water led to improve water application efficiency, contribution of ground water table, nitrogen efficiencies, saving more water, net income, net income from water unit and economical efficiency without observed reduction in maize crop yield.

\section{REFERENCES}

Abd El-Rasool, S.F.; H.W. Tawadros; W.I. Miseha and F.N.Mahrous (1971). Effect of irrigation and fertilization on water use efficiency by wheat. Fertilization Conf. Ain Shams Univ., Cairo, Egypt

Abdel-Maksoud, H. H. ; S. A. Othman and A. Y. El-Tawil (2002). Improving water and $\mathrm{N}$-use utilization via alternate-furrow irrigation technique. J. Agric. Sci. Mansoura Univ., 27(12):8761-8769.

Abo Soliman, M. S. M. ; M. M. Saied ; S. M. El - Barbary and M. M. Ragab (2002). Improvd irrigation technique under reuse of water in North delta, Int.symp.on Optimum Resources Utilization in Salt-Affected Ecosystems in Arid and Semi-Arid Regions, Cairo.8-11 Apr., 2002: 161-169. 
Abou El-Soud ,H. M (2009). Studies on water and salt movement under surface and drip irrigation systems in Nile delta soils. M.Sc. Thesis, Mansoura Univ. Fac. of Agric. Egypt.

Aiad, M. A. M. (2003). Effect of surge irrigation on water consumptive use and nutrient uptake of cotton. M.Sc. Thesis, Mansoura Univ. Fac. of Agric. Egypt.

Brater, E.F. and H.W. King.(1976). Handbook of Hydraulics, McGeavv. Hill Book company. 6l" Ed. NY.

Crasswell. E. T. and D. C. Godwin. (1984). The efficiency of nitrogen fertilizers applied to cereals in different climates. Adv. Plant Nutrition 1, $1-55$.

Downy, LA. (1970). Water use by maize at three plant densities. Paper, 33, FAO, Rome.

Duncan, D. B. (1955). Multiple range and multiple F-test. Biometrics, 11:1-42

Early, A.C. (1975). Irrigation Scheduling for wheat in Punjab, Cento Sci. Prog. Optimum use of water in Agric. RPT. 17, Lyallpur, Pakistan, 3-5 March, $\mathrm{pp}, 115-127$.

Giriappa, S.(1983). Water use efficiency in agriculture Oxford-IBH publishing Co., New Delhi, 6-9

Hesse, P. R. (1971)." A Text Book of Soil Chemical Analysis". Juan Murry (Publisher) Ltd, London.

Israelson, O.W. and V.E. Hansen (1962). "Irrigation Principles and Practices". 3 rd Ed.. John Willey \& Sons. New York.

Jackson, M.L. (1967). Soil Chemical Analysis. Prentice-Hall of India, New Delhi

Kahlown,M.A. ;M. Ashraf and F. Zia-UL-Haq (2005). Effect of shallow ground water table on crop water requirements and crop yield. Agri. Water management 76:24-35.

Kang, S.; Z. Liang ; Y. Pan ; P. Shi and J. Zhang (2000). Alternate furrow irrigation for maize production in an arid area. Agric. Water Manag. 45(3):267-274.

Khalifa, R.M. (2013). Water requirements of maize and sugar beet as affected by soil moisture depletion and water table level. M.Sc. Thesis, kafrelesheikh Univ. Fac. of Agric. Egypt.

Klute , A. (1986) . Methods of Soil Analysis (part 1). Amer. soc. of Agron., Inc. Madison, Wisconsin, USA. 3rd edition.

Michael, A.M. (1978). Irrigation Theory and Practice. Vikas Publishing House, New Delhi, 1978.

Mkhabela M. S. ; M. S. Mkhabela and J. Pali-Shikhulu (2001). Response of maize (Zea moys L.) cultivars to different levels of nitrogen application in Swaziland. Seventh Eastern and Southern Africa Regional Maize Conf. pp.377-381.

Morsi T. M. (2001). A study on irrigation systems developing of furrow irrigation methods for corn crop under local conditions, M.Sc. Thesis, Fac. of Agric., Tanta Univ., Egypt

Mosa, A. A. (2006). Water use efficiency and nutrients uptake as affected by alternate furrow irrigation technique and fertilization of maize. Ph.D. Thesis, Mansoura Univ. Fac. of Agric. Egypt. 
Richards, L. A. (1954). "Diagnosis and Improving of Saline and Alkaline Soils". U. S., Salinity Laboratory Staff. Agric. Handbook, No.60.

Shabana ,M. A (2010). Evaluation of using some modern irrigation techniques to improve surface irrigation system and its effect on nitrogen use efficiency . M.Sc. Thesis, Mansoura Univ. Fac. of Agric. Egypt.

Sonbol, H.A. ; E.M. El-Hadidi ; M.M. Saied and H.M Abou El-Soud (2009).Comparison of some surface and drip irrigation systems on maize crop. J. Agric. Mansoura Univ., 34(6):7199-7210,2009.

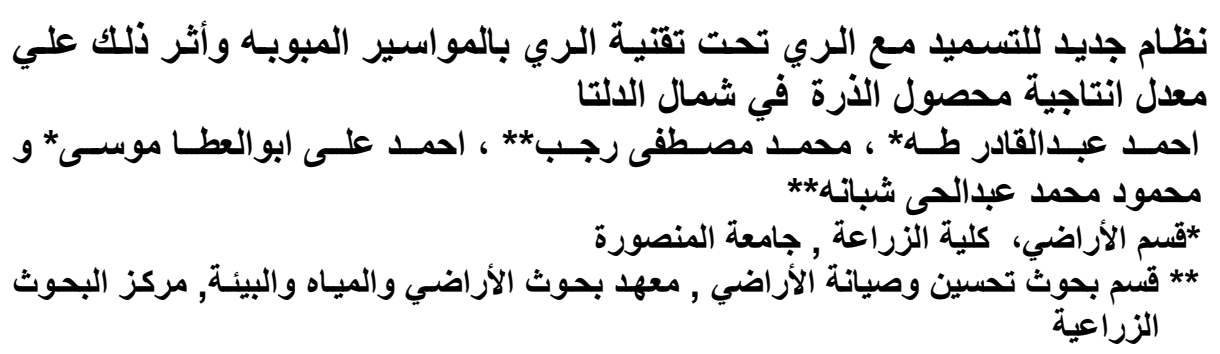

لتحسين كفـاءة استخدام الاسـمده تحت تقتيـة الري بالمو اسبر المبوبـه على بعض العلاقـات المائيـة

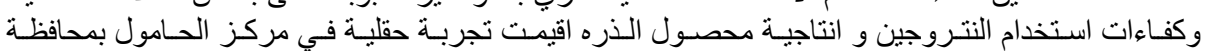

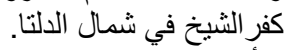

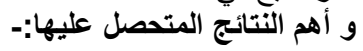

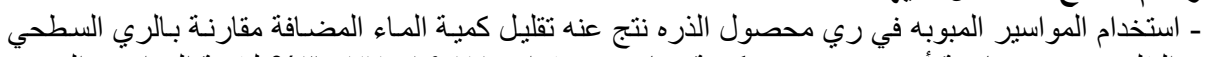

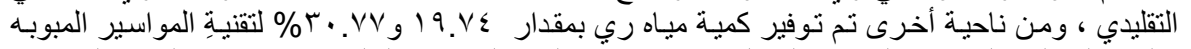

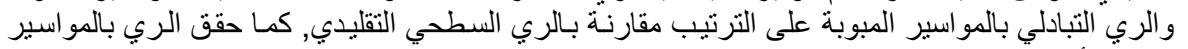

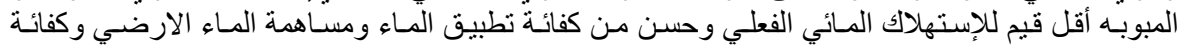

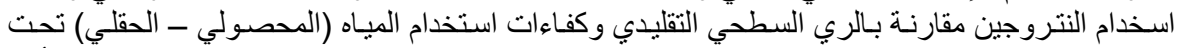

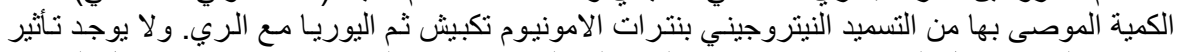

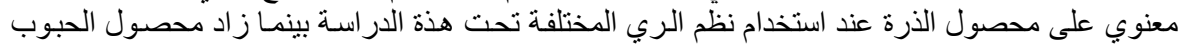

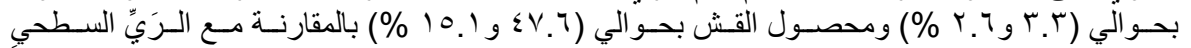

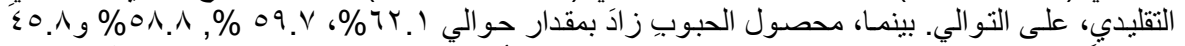

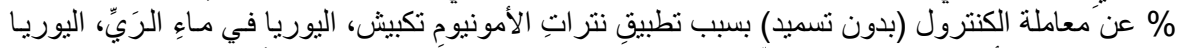

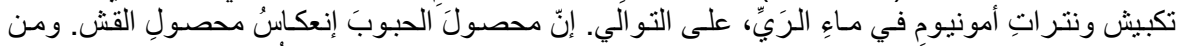

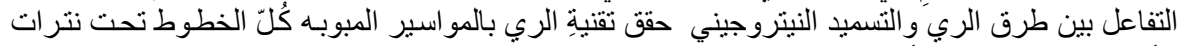

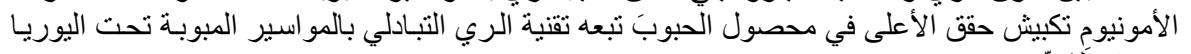

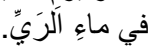

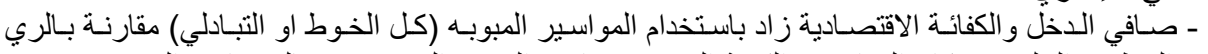
السطحي التقليدي, وكان الزيادة مع الكمية الموصى بها من التنميد النيتروجيني باليوريا مع الري. الري.

$$
\text { كلية الزراعة - جامعة المنصورة الزيه }
$$

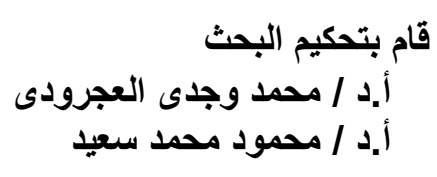

